Ana Luísa Areia*, Sofia Vale-Pereira, Ana Vaz-Ambrósio, Vera Alves, Paulo Rodrigues-Santos, Manuel Santos Rosa, Paulo Moura and Anabela Mota-Pinto

\title{
Does progesterone administration in preterm labor influence Treg cells?
}

DOI 10.1515/jpm-2015-0134

Received April 26, 2015. Accepted July 29, 2015.

\begin{abstract}
Objectives: The aim of this study was to determine if the actions of progesterone on preterm labor are accomplished through modulation of the percentage of regulatory T-cells (Treg).
\end{abstract}

Methods: The study was a cohort pilot study made in a single center tertiary obstetrical unit with women in preterm labor arrested with tocolytic treatment. Variation of the number and percentage of Treg cells obtained from peripheral blood samples of women with preterm labor were calculated by flow cytometry, before and after progesterone administration.

Results: In the paired samples for each patient, there was a significant difference in the Treg cell pool after progesterone treatment, with an increase in both their percentage (48.9 vs. $53 ; \mathrm{P}=0.07)$ and absolute number (14.8 vs. 56.5 cells $/ \mu \mathrm{L} ; \mathrm{P}=0.046)$.

Conclusions: This research demonstrated a considerable increase in the Treg cell pool after progesterone treatment. This indicates a possible mechanism for progesterone treatment benefits in preterm labor, potentially increasing its more rational use.

Keywords: Pregnancy; preterm labor; progesterone; Tregs.

\footnotetext{
*Corresponding author: Ana Luísa Areia, Faculty of Medicine, University of Coimbra, Rua Miguel Torga, 3030-165 Coimbra, Portugal, Tel.: +351 917212222, Fax: +351 239481227, E-mail: analuisareia@gmail.com. http://orcid.org/0000-0003-2371-8907; and Obstetric Unit, Coimbra University Hospital Centre, Faculty of Medicine, University of Coimbra, Coimbra, Portugal Sofia Vale-Pereira, Ana Vaz-Ambrósio, Vera Alves, Paulo Rodrigues-Santos, Manuel Santos Rosa and Anabela Mota-Pinto: Faculty of Medicine, University of Coimbra, Coimbra, Portugal Paulo Moura: Obstetric Unit, Coimbra University Hospital Center, University of Coimbra, Coimbra, Portugal
}

\section{Introduction}

Approximately $12 \%-13 \%$ of pregnancies in the USA and $5 \%-9 \%$ in other developed countries end prematurely, often as a result of contractions that cannot be inhibited by tocolytic treatment [1]. Perinatal mortality from preterm labor (PTL) reaches $75 \%$ [2] and it seems to be linked to high levels of inflammatory cytokines [3].

Inflammatory pathways stimulate events that lead to parturition such as cervical ripening, rupture of membranes and uterine contractions [2], and premature activation of these inflammatory cascades is thought to be responsible for the initiation of PTL [1].

Currently it is not known whether immunological rejection processes participate in the induction of irresistible preterm labor [1], although the host's immune response is presumed to lead to the inflammatory response and preterm labor [4].

$\mathrm{CD}^{+}{ }^{+} \mathrm{T}$-cells are important agents in the establishment of pregnancy, and the Th1/Th2 paradigm has been expanded to include $\mathrm{CD}^{+}$regulatory $\mathrm{T}$ (Treg) cells [5]. Treg cells represent about $5 \%$ of the peripheral $\mathrm{CD} 4^{+} \mathrm{T}$-cell population and are recognized as a major cell subset at peripheral immune tolerance. They have a suppressive effect on inflammatory responses and are one of the candidates to explain maternal tolerance mechanisms regarding the conceptus [6].

First considered to be a homogeneous population, Treg cells are now recognized as having two distinct pathways of generation distinguished by having different antigen specificities and T-cell receptor signal strengths and co-stimulatory requirements. The two main groups of Treg cells are natural Treg cells (nTreg ) and induced or adaptive Treg cells (iTreg ) [7]. nTreg cells generated in the thymus in a continuous mode by a selection process [6] express high levels of the IL-2 receptor $\alpha$-chain (CD25) and the forkhead/winged helix transcription factor FoxP3, which is indispensable for their development and function. iTreg cells emerge from T-cells in the periphery after exposure to antigens in the peripheral lymphoid organs $[5,6]$. Under the influence of suppressive cytokines and antigen-specific activation, they develop into FoxP3 ${ }^{+}$Treg 
[7]. Over the years, the careful study of Treg cells gave rise to the question of what Treg cell subtype is actually acting in pregnancy [5].

Presently, it is not known if the mechanisms leading to PTL are associated with deficient Treg function [8], but recent research points to an abnormal alteration in the proportion of Treg cells that might modulate maternal immune homeostasis [9].

The placenta is the primary site of progesterone synthesis throughout pregnancy in humans [2]. Progesterone is a critical immunomodulatory hormone in the regulation of human T-cell population during pregnancy, as it leads to a series of functional events in numerous immune cell types [10]. With the combination of its pro-effects on Th2 and Treg cells, progesterone contributes to the establishment of a favorable environment for pregnancy [5], favoring Th2 $\mathrm{CD}^{+} \mathrm{T}$-cell development and Th2 dominance [11].

$\mathrm{T}$ lymphocytes, but not other immune cell types, appear to respond to progesterone, suggesting a reciprocal role in regulating the immune system and, therefore, parturition [2]. In addition, physiological doses of progesterone expand Treg cells, enhance in vitro Treg cell function and induce a Treg phenotype in activated responder T-cells [12].

Since 2010, there have been investigations surrounding the role of Treg cells in pregnancy. Most authors use animal models (namely mice), as investigation in humans is harder to accomplish. Nevertheless, human pregnancy has unique features that differentiate it from other mammals, so animal results must be regarded with caution.

Most studies and meta-analysis of progesterone and PTL focus on the issue of prophylactic administration of progesterone by vaginal [13-16], intramuscular [17-23] or oral routes [24], in the presence of a previous preterm delivery or short cervix. In the literature, the number of trials and meta-analyses on the use of progesterone after an effective PTL treatment is small, but their results were promising and suggest an increased benefit with progesterone use [14, 19, 25, 26].

Consequently, progesterone supplementation for women with threatened preterm labor has been investigated based on several plausible modes of action [27], although the exact mechanism by which progesterone can exert its effects is still unidentified [28]. However, due to the high economical and health burden associated with prematurity, finding the exact mechanism by which progesterone accomplishes its immunomodulatory role would allow a justification, refinement and generalization of its use. It is the aim of this study to investigate whether the actions of progesterone on preterm labor are accomplished through Treg cell regulation.

\section{Materials and methods}

We undertook a pilot exploratory study consisting of a cohort of pregnant women with threatened preterm labor attending our obstetrics unit between December 2013 and August 2014.

Inclusion criteria consisted of admission in the obstetric unit of Coimbra University Hospital Center with confirmed preterm labor, singleton pregnancy, gestational age between 24 weeks +0 days and 33 weeks +6 days, intact amniotic membranes, cervical length $\leq 25 \mathrm{~mm}$ and use of atosiban (competitive antagonist of oxytocin receptors) for tocolysis.

Exclusion criteria were multiple gestation, pre-existing disease, preterm rupture of membranes, chorioamnionitis, placenta praevia, placental abruption, clinical signs of infection (maternal temperature $\geq 37.5^{\circ} \mathrm{C}$, white blood cells $\geq 15,000$ cells $/ \mathrm{mm}^{3}$ in maternal blood) or usage of hormone therapies within 3 months before enrolment. The presence of risk factors was defined as existence of a previous PTL and/or tobacco use.

Gestational age was assessed by the date of the last menstrual period or by ultrasound.

Administration of natural progesterone was done after tocolysis with $200 \mathrm{mg}$ once daily atosiban. The vaginal route was chosen due to higher bioavailability, fewer secondary effects, rapid absorption and additional local effects on the endometrium. Peripheral blood samples were obtained on two occasions: after tocolysis with atosiban - before first progesterone administration - and $24 \mathrm{~h}$ after treatment with $200 \mathrm{mg}$ daily vaginal natural progesterone.

The Ethical Committees of Coimbra University Faculty of Medicine and Coimbra University Hospital approved the investigation and informed consent was obtained from each participant.

\section{Specimen collection}

Peripheral venous blood samples were obtained and collected in lithium heparin tubes. Samples were kept in a cool environment until they were processed, within $1 \mathrm{~h}$ of collection.

\section{Flow cytometry staining}

In brief, membrane staining of whole blood containing $0.5-1 \times 10^{6}$ white blood cells was performed with PB-conjugated anti-CD4, PE-Cy7-conjugated anti-CD25 and PerCP-Cy 5.5-conjugated antiCD127 antibodies, all purchased from Biolegend (Biolegend, San Diego, CA, USA).

Subsequently, we used a staining set (eBioscience, San Diego, CA, USA) and AF647-labeled anti-human FoxP3 (Biolegend, San Diego, CA, USA) to perform the intracellular staining for detection of FoxP3, following the manufacturer's instructions. Flow cytometry data were acquired on a FACS Canto II instrument (BD Biosciences, USA) equipped with three lasers to allow multicolor detection with different fluorophores, using FACS DIVA software (BD Biosciences, USA).

Lymphocyte populations were selected according to the forward angle (FSC-A) and side angle (FSC-H) scattering signal, and at least 50,000 gated lymphocyte cells were detected for each sample. Dead cells were excluded by forward and side scatter characteristics, 
and an FSC-A vs. FSC-H dot plot was used to discriminate doublets, detecting disparity between cell size vs. cell signal. Isotype control antibodies were used to help assess the level of background staining, as well as samples without staining and single stain, for each antibody.

\section{Treg analysis}

Gating strategies were employed to evaluate the percentage of $\mathrm{CD} 4^{+} \mathrm{CD} 25^{\text {high }} \mathrm{CD} 127^{\text {low }}$ cells, the percentage of Treg cells in total $\mathrm{CD} 4^{+}$ T-cells and the mean fluorescence intensity (MFI) of FoxP3 in the $\mathrm{CD} 4^{+} \mathrm{CD} 25^{\text {high }} \mathrm{CD} 127^{\text {low }} \mathrm{Foxp} 3$ population. Our gating strategy for identifying the Treg population was based on a total lymphocyte gate based on FSC/Side light scatter (SSC) dot plot followed by doublet discrimination with an FSC-A vs. FSC-H dot-plot. Accordingly, CD4 positive cells were gated over SSC characteristics; depending on CD25 and CD127 expression, $\mathrm{CD}^{+}$cells were gated based on the expression of $\mathrm{CD} 25^{\text {high }}$ and $\mathrm{CD} 127^{\text {low }}$ markers, and therefore $\mathrm{CD} 4+\mathrm{CD} 25^{\text {high }} \mathrm{CD} 127^{\text {low }}$ population was detected.

As the literature varies when considering markers for the exact phenotype of a Treg cell population, we moved on to the $\mathrm{CD}^{+} \mathrm{CD} 25^{\text {high }} \mathrm{CD} 127^{\text {lowpopulation }}$ and also searched for $\mathrm{FoxP}^{+}$ cells. We defined our regulatory T-cell population as being the $\mathrm{CD}^{+} \mathrm{CD} 25^{\text {high }} \mathrm{CD} 127^{\text {low }} \mathrm{FoxP}^{+}$.

Statistical analysis was based on at least 15,000-20,000 gated CD4 ${ }^{+}$cells.

FlowJo software (Tree Star Data Analysis Software, Ashland, USA) was used for flow cytometry analysis. We also performed an absolute count on each population based on lymphocyte number present in hemogram.

\section{Statistical analysis}

Data were analyzed by IBM SPSS statistics version 21 software and expressed as mean \pm standard deviation (SD) or as median and interquartile range (IQR), as appropriate for the type of distribution. Statistical comparison between samples of the same patient was done using the Wilcoxon Signed Rank Test for the total number and percentage of $\mathrm{CD} 4^{+} \mathrm{CD} 25^{\text {high }} \mathrm{CD} 127^{\text {low }}$ population, the total number and percentage of the Treg cell subset within the total $\mathrm{CD} 4^{+} \mathrm{CD} 25^{\text {high }} \mathrm{CD} 127^{\text {low }}$ population and FoxP3 ${ }^{+}$MFI. Statistical significance was considered at a two-sided $\mathrm{P}$-value $<0.05$. There were no missing data in our population sample.

\section{Results}

A total of 20 peripheral venous blood samples were extracted from 10 pregnant women presenting with PTL, divided equally before and after progesterone treatment. Clinical data of the population are shown in Table 1.

PTL women had a mean age of $33 \pm 4.1$ years, with a mean gestational age of $31.2 \pm 2.0$ weeks, showing a mean cervical length of $19 \pm 4.3 \mathrm{~mm}$. These data reflect the strict inclusion criteria used in the study.
Table 1: Clinical data.

\begin{tabular}{lr}
\hline Variable & Value \\
\hline $\mathrm{n}=10$ patients & \\
Age (years) & $33 \pm 4.1$ \\
$\quad$ Mean \pm SD & $(26-37)$ \\
$\quad$ (min-max) & \\
Gestational age (weeks) & $31.2 \pm 2.0$ \\
$\quad$ Mean \pm SD & $(26-33)$ \\
$\quad(m i n-m a x)$ & \\
Cervical length (mm) & $19 \pm 4.3$ \\
$\quad$ Mean \pm SD & $(13-25)$ \\
$\quad$ (min-max) & $60 \%$ \\
Multipara (proportion) & $60 \%$ \\
Presence of risk factors ${ }^{\text {a }}$ (proportion) & \\
\hline
\end{tabular}

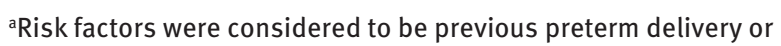
tobacco use.

For the isolation of the specific lymphocyte population, CD4 $4^{+}$T-cells first were gated and CD25 and CD127 expression was analyzed. Subsequently, the number and percentage of $\mathrm{CD} 4^{+} \mathrm{CD} 25^{\text {high }} \mathrm{CD} 127^{\text {low }}$ cells were estimated for all participants. Afterwards, this population was characterized in terms of the expression of FoxP3 to estimate both the percentage and absolute number of Treg cells. FoxP3 MFI on Treg cells was also estimated for all participants.

Figure 1 shows an example of the $\mathrm{CD}^{+} \mathrm{CD} 25^{\text {high }}$ $\mathrm{CD}_{12} 7^{\text {low }} \mathrm{FoxP}^{+}$population (regulatory T-cell population) in peripheral blood, before and after progesterone treatment.

Table 2 shows the comparison between T-cell populations in blood before and after progesterone treatment, and all results represent the paired samples for each patient.

As is shown, there was a statistically significant increase after progesterone treatment in the percentage of $\mathrm{CD}^{+} \mathrm{T}$-cells, with an increase in their proportion of 44.6 vs. $60.2(\mathrm{P}=0.013)$. An enhancement after progesterone administration could also be verified in both the percentage and absolute number of the $\mathrm{CD} 4^{+} \mathrm{CD} 25^{\text {high }} \mathrm{CD} 127^{\text {low }}$ population, although not reaching statistical significance. As for the Treg cell population (those cells expressing the intracellular marker Foxp3), there was a significant increase after progesterone treatment in both their percentage (48.9 vs. $53 ; \mathrm{P}=0.07)$ and absolute number (14.8 vs. $56.5 ; \mathrm{P}=0.046)$.

To ascertain whether the number or percentage of $\mathrm{CD}^{+}$cells, $\mathrm{CD} 4^{+} \mathrm{CD} 25^{\text {high }} \mathrm{CD} 127^{\text {low }}$ or Treg cells varied with different clinical characteristics, a subgroup analysis was done for confounding variables such as parity (nullipara vs. multipara) or of the existence of risk factors. The 

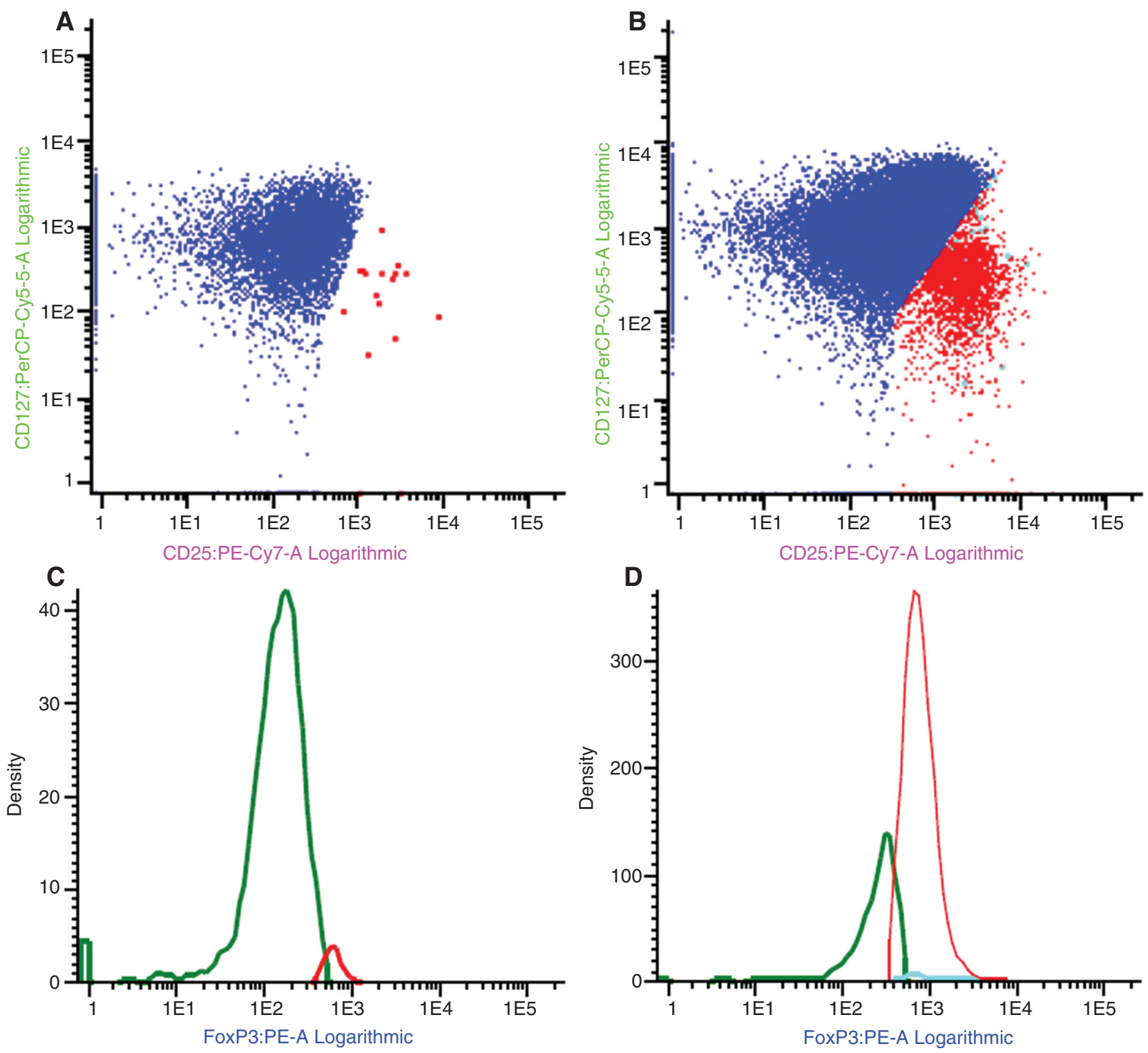

Figure 1: Representative sample of the variation of regulatory T-cell population ( $\left.C D 4^{+} C D 25^{\text {high }} C D 127^{\text {low } F o x P 3}\right)$ in peripheral blood with progesterone administration.

Dot- plots representation with regulatory T-cell population marked in red. (A) Before progesterone treatment; (B) after progesterone treatment. Histograms representing the regulatory T-cell population marked in red and the $\mathrm{CD}^{+}{ }^{+} \mathrm{CD} 25^{\text {high }} \mathrm{CD} 127^{\text {low }}$ FoxP3- population in green.

(C) Before progesterone treatment; (D) after progesterone treatment.

analysis revealed that the difference in the Treg cell pool was mainly at the expense of the nullipara group, where the increase of the Treg cells percentage after progesterone treatment was 30 vs. $71 ; \mathrm{P}=0.07$.

Moreover, in the group of women without risk factors, the increase in the percentage of the Treg cell pool after progesterone treatment was also relevant (59 vs. 75 ; $\mathrm{P}=0.07)$.

No other comparisons between groups had statistical significance.

\section{Discussion}

According to the World Health Organization, there are 13 million preterm babies born each year worldwide. Despite the various measures to reduce this problem, the incidence of preterm labor has increased worldwide, and continues to be a relatively common pathology. In the quest for a novel agent in PTL treatment, progesterone emerges as a good candidate due to its immunomodulator action, supposedly acting as the critical regulator of 
Table 2: Comparison between T-cell populations in blood according to progesterone treatment.

\begin{tabular}{|c|c|c|c|}
\hline \multirow{2}{*}{$\begin{array}{l}\text { Lymphocyte } \\
\text { population }\end{array}$} & \multicolumn{2}{|c|}{ Progesterone treatment } & \multirow[t]{2}{*}{ P-value } \\
\hline & Before & After & \\
\hline \multicolumn{4}{|l|}{$\mathrm{CD4}^{+}$} \\
\hline Percentage & $44.6(31)$ & $60.2(14)$ & 0.013 \\
\hline Absolute number ${ }^{\mathrm{a}}$ & $730(1603)$ & $1261(1606)$ & 0.2 \\
\hline \multicolumn{4}{|l|}{$\mathrm{CD}_{4}{ }^{+} \mathrm{CD} 25^{\text {high }} \mathrm{CD} 127^{\text {low }}$} \\
\hline Percentage & $8(4.7)$ & $8.7(6.4)$ & 0.3 \\
\hline Absolute number ${ }^{\mathrm{a}}$ & $41(170)$ & 135 (159) & 0.3 \\
\hline \multicolumn{4}{|l|}{ Tregs $^{b}$} \\
\hline Percentage & $48.9(54.6)$ & $53(37.4)$ & 0.07 \\
\hline Absolute number ${ }^{a}$ & $14.8(33.9)$ & $56.5(118)$ & 0.046 \\
\hline MFI FoxP3 $3^{+}$ & $823(545)$ & $839(233)$ & 0.7 \\
\hline
\end{tabular}

All data are presented as median and interquartile range; anumber cells/ $\mu$ L blood; ' ${ }^{T}$ Tregs: $C D 4{ }^{+} C D 25^{\text {high }} \mathrm{CD} 127^{\text {low }}$ Foxp3 ${ }^{+}$; 'Wilcoxon Signed Rank Test with a significance level of 0.05 (in bold results $<0.05)$; $\mathrm{MFI}=$ Mean fluorescence intensity.

Treg cells during pregnancy by an unknown mechanism. Human studies are nonexistent in this field, and this research proposes an innovation in the understanding of preterm labor and its treatment.

To our knowledge, this is the first article focusing on the role of progesterone treatment on Treg cells in cases of PTL. Related preceding research investigated PTL' risk prediction using cervical length and Treg cells [29] and not progesterone's immune effects.

We demonstrated that there was a significant increase after progesterone treatment in the Treg cell pool with a rise both in their percentage $(48.9 \%$ vs. $53 \%$; $\mathrm{P}=0.07)$ and absolute number (14.8 vs. $56.5 ; \mathrm{P}=0.046)$. This confirms the knowledge that progesterone contributes to the establishment of a favorable environment for pregnancy [5] and the enhancement of Treg cell function in vitro [12]. Moreover, it corroborates existent data hypothesizing an inflammation-triggered inadequate immunologic response that prompts PTL [30].

The fact that changes in the Treg cell pool were more pronounced in the nullipara group ( $30 \%$ vs. $71 \% ; \mathrm{P}=0.07)$ and in women without risk factors ( $59 \%$ vs. $75 \%$; $\mathrm{P}=0.07$ ) confirms the complexity of preterm labor. It is more certainly a syndrome than a single disease, being triggered by different mechanisms in diverse circumstances. This imposes the need for further investigation about the causes and risk factors of this syndrome.

Besides being the first human investigation regarding Treg cell changes after specific treatment with progesterone in PTL, our study has strict inclusion and exclusion criteria, bringing together women with similar clinical characteristics (and without confounding pathologies), making our results reliable. Also, it is an original study as the same determinations were made for each patient before and after a certain treatment. Moreover, as the samples were taken $24 \mathrm{~h}$ after progesterone administration, we ascertained that the alterations in the Treg cell pool are due to that treatment, and not to normal evolutionary changes in pregnancy. In fact, blood peak progesterone concentrations are attained $4 \mathrm{~h}$ after vaginal administration with a half-life of about $13 \mathrm{~h}$ [31]; as so, most authors reported an ideal $24 \mathrm{~h}$ interval to demonstrate progesterone's immune effects [12].

As materials and methods are thoroughly explained, our investigation is reproducible.

In the literature, there are four articles reporting studies of Treg cells in pregnant women with PTL [1, 8, 9, 29], although none of them studied the influence of progesterone treatment on the Treg cell population. Moreover, aims, inclusion criteria, T-cell population studied and conclusions are different among the four studies.

The article of Xiong et al. was the first to demonstrate changes in circulating $\mathrm{CD}^{+}{ }^{+} \mathrm{CD} 25^{\text {high }} \mathrm{FoxP}^{+}$Tregs in PTL [9], and their work evidenced a lower proportion of that particular T-cell population in PTL. Although including only one sample of 31 women, the definition of Treg cell population was different, not including the CD127 marker. Nevertheless, these results make our study even more consistent, highlighting the importance of progesterone administration in increasing the Treg cell pool in PTL women.

Kisielewicz et al. [8] studied the parallelism between PTL and organ transplant rejection. The results showed that in PTL, Treg cells show a reduced suppressive activity of their circulating $\mathrm{CD} 4^{+} \mathrm{CD} 25^{\text {high }} \mathrm{CD} 127^{\text {low }}$ cells and a decrease in the level of HLA DR ${ }^{+}$expression. However, of the 21 PTL women included (already excluding preterm premature rupture of membranes and cervical incompetency), there were no excluding criteria and there was only one sample for each patient.

Schober et al. considered the suppressive activity and changes in the composition of the regulatory T-cell pool [1]. They included 46 PTL women, but no exclusion criteria were used and the definition of PTL cases included preterm premature rupture of membranes and cervical incompetency. Their results inferred a decrease in the percentage of HLA DR+Treg cells, in HLA DR expression and a decrease in the suppressive activity of Treg cells.

Recent interesting research from Koucky et al. aimed to determine the early predictors of PTL, using cervical length and Treg cells [29]. In the cohort of 60 highrisk women included, they showed that the combined 
assessment of Treg cell count and cervical length was a better predictor of preterm delivery than either parameter used on its own. Although this study included women using progesterone, it differed from our investigation as its purpose was PTL risk estimation and not treatment. Additionally, the definition of the Treg cell pool is not unanimous among authors, nor is the definition of women at risk.

Furthermore, our results present differences between percentages and absolute numbers; this is due to the multiple calculations needed to obtain the different minor blood populations and to the several roundings required. However, to the authors, it seemed more accurate to present both results as some articles present the results as percentages and other as absolute numbers.

Our study also has limitations: the number of patients included is limited and the functionality of the Treg cell pool of those patients should also be analyzed. How progesterone acts on T-cells is still under dispute, with some researchers defending both nuclear and non-nuclear contribution of receptors [11]. Consequently, in a near future, an investigation regarding which type of progesterone receptor regulates Treg cells and explaining progesterone actions on PTL treatment is desirable.

This research demonstrated a significant increase in the Treg cell pool after progesterone treatment, indicating a possible mechanism by which its beneficial role in PTL is achieved.

Ultimately, this will enable obstetricians to understand progesterone's role in preterm labor and to establish a secure and safe clinical protocol in PTL treatment.

Acknowledgments: This research received supporting funding from the Office of Research Support, Faculty of Medicine, University of Coimbra, Portugal.

\section{References}

[1] Schober L, Radnai D, Schmitt E, Mahnke K, Sohn C, Steinborn A. Term and preterm labor: decreased suppressive activity and changes in composition of the regulatory T-cell pool. Immunol Cell Biol. 2012;90:935-44.

[2] Byrns MC. Regulation of progesterone signaling during pregnancy: implications for the use of progestins for the prevention of preterm birth. J Steroid Biochem Mol Biol. 2014;139:173-81.

[3] Zachariades E, Mparmpakas D, Pang Y, Rand-Weaver M, Thomas P, Karteris E. Changes in placental progesterone receptors in term and preterm labour. Placenta. 2012;33:367-72.

[4] Thaxton JE, Nevers TA, Sharma S. TLR-mediated preterm birth in response to pathogenic agents. Infect Dis Obstet Gynecol. 2010;2010.
[5] Polese B, Gridelet V, Araklioti E, Martens H, Perrier d'Hauterive S, Geenen V. The endocrine milieu and CD4 T-lymphocyte polarization during pregnancy. Front Endicrinol. 2014;5:106.

[6] Leber A, Teles A, Zenclussen AC. Regulatory T cells and their role in pregnancy. Am J Reprod Immunol. 2010;63:445-59.

[7] Lastovicka J. The phenotypic markers of CD4+CD25+ T regulatory lymphocytes. Res Immunol. 2013;2013:1-14.

[8] Kisielewicz A, Schaier M, Schmitt E, Hug F, Haensch GM, Meuer S, et al. A distinct subset of HLA-DR+-regulatory T cells is involved in the induction of preterm labor during pregnancy and in the induction of organ rejection after transplantation. Clin Immunol. 2010;137:209-20.

[9] Xiong H, Zhou C, Qi G. Proportional changes of CD4+CD25+Foxp3+ regulatory T cells in maternal peripheral blood during pregnancy and labor at term and preterm. Clin Invest Med. 2010;33:E422.

[10] Dressing GE, Goldberg JE, Charles NJ, Schwertfeger KL, Lange CA. Membrane progesterone receptor expression in mammalian tissues: a review of regulation and physiological implications. Steroids. 2011;76:11-17.

[11] Lee JH, Lydon JP, Kim CH. Progesterone suppresses the mTOR pathway and promotes generation of induced regulatory T cells with increased stability. Eur J Immunol. 2012;42:2683-96.

[12] Mao G, Wang J, Kang Y, Tai P, Wen J, Zou Q, et al. Progesterone increases systemic and local uterine proportions of CD4+CD25+ Treg cells during midterm pregnancy in mice. Endocrinology. 2010;151:5477-88.

[13] da Fonseca EB, Bittar RE, Carvalho MH, Zugaib M. Prophylactic administration of progesterone by vaginal suppository to reduce the incidence of spontaneous preterm birth in women at increased risk: a randomized placebo-controlled doubleblind study. Am J Obstet Gynecol. 2003;188:419-24.

[14] Dodd JM, Flenady VJ, Cincotta R, Crowther CA. Progesterone for the prevention of preterm birth: a systematic review. Obstet Gynecol. 2008;112:127-34.

[15] Fonseca EB, Celik E, Parra M, Singh M, Nicolaides KH. Progesterone and the risk of preterm birth among women with a short cervix. N Engl J Med. 2007;357:462-9.

[16] O’Brien JM, Adair CD, Lewis DF, Hall DR, Defranco EA, Fusey S, et al. Progesterone vaginal gel for the reduction of recurrent preterm birth: primary results from a randomized, doubleblind, placebo-controlled trial. Ultrasound Obstet Gynecol. 2007;30:687-96.

[17] Dodd JM, Crowther CA, Cincotta R, Flenady V, Robinson JS. Progesterone supplementation for preventing preterm birth: a systematic review and meta-analysis. Acta Obstet Gynecol Scand. 2005;84:526-33.

[18] Dodd JM, Flenady V, Cincotta R, Crowther CA. Prenatal administration of progesterone for preventing preterm birth. Cochrane Database Syst Rev. 2006;1:CD004947.

[19] Facchinetti F, Paganelli S, Comitini G, Dante G, Volpe A. Cervical length changes during preterm cervical ripening: effects of 17-alpha-hydroxyprogesterone caproate. Am J Obstet Gynecol. 2007;19:453.e451-4; discussion 421.

[20] Mackenzie R, Walker M, Armson A, Hannah ME. Progesterone for the prevention of preterm birth among women at increased risk: a systematic review and meta-analysis of randomized controlled trials. Am J Obstet Gynecol. 2006;194:1234-42. 
[21] Meis PJ, Klebanoff M, Thom E, Dombrowski MP, Sibai B, Moawad AH, et al. Prevention of recurrent preterm delivery by 17 alpha-hydroxyprogesterone caproate. N Engl J Med. 2003;348:2379-85.

[22] Rouse DJ, Caritis SN, Peaceman AM, Sciscione A, Thom EA, Spong $\mathrm{CY}$, et al. A trial of 17 alpha-hydroxyprogesterone caproate to prevent prematurity in twins. N Engl J Med. 2007;357:454-61.

[23] Sanchez-Ramos L, Kaunitz AM, Delke I. Progestational agents to prevent preterm birth: a meta-analysis of randomized controlled trials. Obstet Gynecol. 2005;105:273-9.

[24] Erny R, Pigne A, Prouvost C, Gamerre M, Malet C, Serment H, et al. The effects of oral administration of progesterone for premature labor. Am J Obstet Gynecol. 1986;154:525-9.

[25] Borna S, Sahabi N. Progesterone for maintenance tocolytic therapy after threatened preterm labour: a randomised controlled trial. Aust NZ J Obstet Gynaecol. 2008;48:58-63.

[26] Areia A, Fonseca E, Moura P. Progesterone use after successful treatment of threatened pre-term delivery. J Obstet Gynaecol. 2013;33:678-81.
[27] Creasy RK, Resnik R, lams JD, Lockwood CJ, Greene MF, Moore T. Creasy and Resnik's maternal-fetal medicine: principles and practice. Elsevier Health Sciences; 2013.

[28] Rai P, Rajaram S, Goel N, Ayalur Gopalakrishnan R, Agarwal R, Mehta S. Oral micronized progesterone for prevention of preterm birth. Int J Gynaecol Obstet. 2009;104:40-3.

[29] Koucky M, Malickova K, Cindrova-Davies T, Germanova A, Parizek A, Kalousova M, et al. Low levels of circulating T-regulatory lymphocytes and short cervical length are associated with preterm labor. J Reprod Immunol. 2014;106:110-7.

[30] Holst D, Garnier Y. Preterm birth and inflammation-The role of genetic polymorphisms. Eur J Obstet Gynecol Reprod Biol. 2008;141:3-9.

[31] Norwitz ER, Caughey AB. Progesterone supplementation and the prevention of preterm birth. Rev Obstet Gynecol. 2011;4:60-72.

The authors stated that there are no conflicts of interest regarding the publication of this article. 